\title{
VENTURE CAPITAL - SUCCESS FACTOR FOR BUSINESS IDEAS
}

\author{
Dr. Subhash K. B.*
}

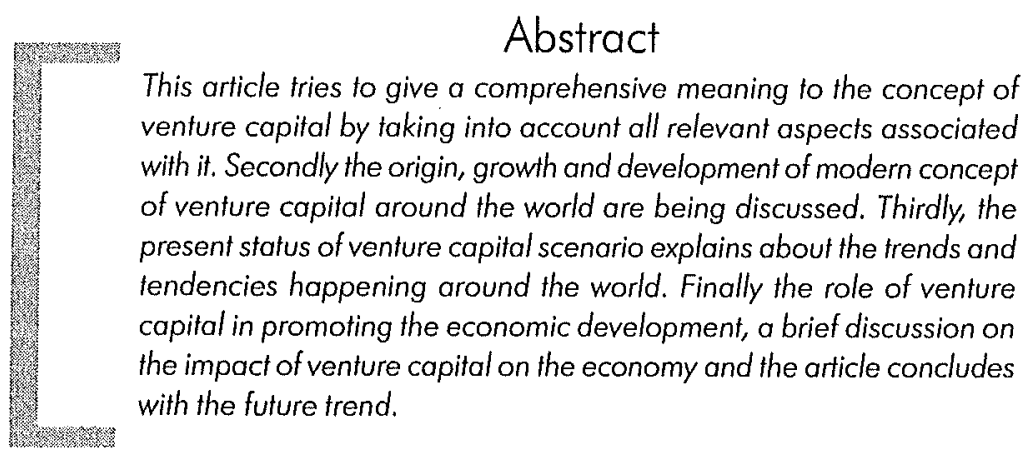

\section{Venture Capital - A Comprehensive Description}

As it is a well established fact that Venture capital is a special type of finance available; to new and innovative novel ventures or ventures having untried technology or ventures having high growth potentiality with high-risk involvement; in the form of mainly equity (sometimes quasi equity or conditional debt) to those

* Leclurer, Department of Commerce, Goa University, Taleigao Plateau, Goa-403206 
entrepreneurs who are having the technical or professional qualifications for starting up the venture and also efficiently managing the venture.' These 'would be' entrepreneurs organize all other required resources with the help of the venture capital raised and make the potential business idea pass through different stages of business cycle; as all businesses have a 'life cycle' which involve stage of growth and development, which can be broadly categorized into Iwo; viz.; early stages and later stages. If the idea passes through these stages successfully, one can see the birth of emerging successful enterprises, which in turn leads to the development of the economy. This happens only if the intangible ideas of entrepreneurs are financed with tangible money by the venture capitalists in the form of venture capital.

This special category of venture capital financing is provided by yet another special category of entrepreneurs technically called venture capitalists. In this noble and also special task wherein new enterprises are born; the joint efforts of both types of entrepreneurs are equally important. The first category of entrepreneur with the novel idea makes sure that it succeeds in becoming an enterprise. For him the product becomes a reality when the enterprise is born and subsequently he can sell the products and start earning returns. For the second category of entrepreneur, the product itself is the enterprise, which he sells once it start generating returns. As he is a professional moneylender, he can do the selection very easily. And also he knows what is to be done, because the good venture capitalist is also an entrepreneur who understands entrepreneurism. ${ }^{2}$

Thus venture capital finance is intermediated external investment in small- and medium-sized companies that offer the prospect of above average earnings growth couples with above average levels of investment risk. The investment process consists of raising a fund, then screening, selecting, structuring, and monitoring investment. Finally, investments must be sold and the capital repaid to investors. ${ }^{3} \mathrm{~A}$ comprehensive diagram showing all these details is shown in Figure -1 .

Figure-1 is based on the assumption that venture capital assistance follows the pattern of the life cycle of the business one after the other till the final stage where the business idea fruitions into an enterprise. From the inception till the IPO, venture capitalist goes hand in hand with the entrepreneur turned owner of the enterprise. This is because unlike any other financing, venture capitalists performs one additional task known as 'Value Addition' wherein they actively take part in the 


\section{FIGURE - 1: CONCEPT OF VENTURE CAPITAL - A COMPREHENSIVE VIEW}

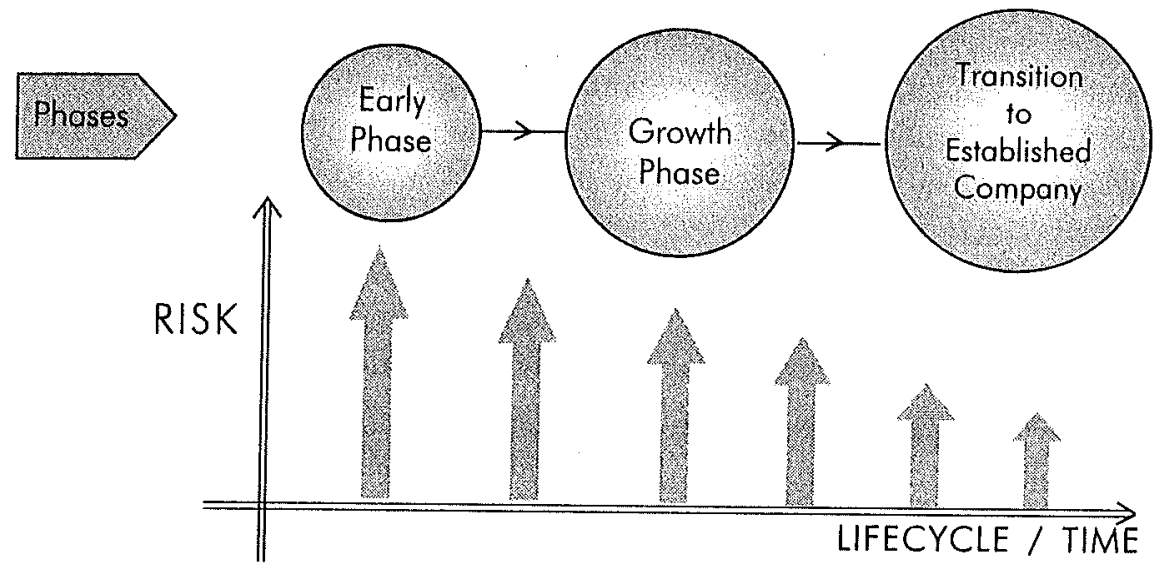

\begin{tabular}{|c|c|c|c|c|c|c|}
\hline 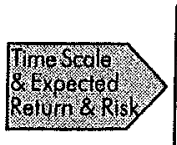 & $\begin{array}{l}7-10 \text { Years } \\
60 \% \text { Return } \\
\text { Extremely } \\
\text { High }\end{array}$ & $\begin{array}{l}5-10 \text { Years } \\
40-60 \% \\
\text { Return } \\
\text { Very High }\end{array}$ & $\begin{array}{l}3-7 \text { Years } \\
30-40 \% \\
\text { Relurn } \\
\text { High }\end{array}$ & $\begin{array}{l}1-3 \text { Years } \\
25-35 \% \\
\text { Return } \\
\text { Medium }\end{array}$ & $\begin{array}{l}1-3 \text { Years } \\
20-30 \% \\
\text { Return } \\
\text { Low }\end{array}$ & $\begin{array}{l}\text { 1-3 Years } \\
20-30 \% \\
\text { Return } \\
\text { Very Low }\end{array}$ \\
\hline
\end{tabular}

\begin{tabular}{|c|c|c|c|c|c|c|}
\hline Fon, & $\begin{array}{l}\text { Idea to } \\
\text { Prototype }\end{array}$ & $\begin{array}{l}\text { Prolotype } \\
\text { to Product }\end{array}$ & $\begin{array}{l}\text { Product to } \\
\text { Market }\end{array}$ & $\begin{array}{l}\text { Market } \\
\text { Growth }\end{array}$ & $\begin{array}{l}\text { Market } \\
\text { Consolidation }\end{array}$ & $\begin{array}{c}\text { Market } \\
\text { Domination }\end{array}$ \\
\hline Business Stalo & $\begin{array}{l}\text { Laboratory } \\
\text { or Workshop }\end{array}$ & $\begin{array}{l}\text { Incubator or } \\
\text { Own Premises }\end{array}$ & $\begin{array}{l}\text { Global } \\
\text { Research }\end{array}$ & $\begin{array}{l}\text { Global } \\
\text { Focus }\end{array}$ & $\begin{array}{l}\text { Global } \\
\text { Premises }\end{array}$ & $\begin{array}{l}\text { IPO Trade } \\
\text { Sale Merger }\end{array}$ \\
\hline
\end{tabular}

\begin{tabular}{|c|c|c|c|c|c|c|}
\hline Wharstoge & Seed & $\begin{array}{l}\text { Startup } \\
\text { (1st round) }\end{array}$ & $\begin{array}{l}\text { Market } \\
\text { Penetration } \\
\text { (2nd round) }\end{array}$ & \begin{tabular}{|l|} 
Market \\
Expansion \\
(3rd round)
\end{tabular} & \begin{tabular}{|l|} 
Mezzanine \\
(Bridge \\
Stage) \\
\end{tabular} & $\begin{array}{l}\text { Liquidity } \\
\text { Event (LE) } \\
\text { OR Exit }\end{array}$ \\
\hline
\end{tabular}

\begin{tabular}{|l|l|l|l|l|l|}
\hline $\begin{array}{l}\text { Whan } \\
\text { Before } \\
\text { Startup }\end{array}$ & $\begin{array}{l}\text { At or shortly } \\
\text { after start-up }\end{array}$ & $\begin{array}{l}\text { At first } \\
\text { growth } \\
\text { spurt }\end{array}$ & $\begin{array}{l}\text { At second } \\
\text { growth spurt } \\
\text { IPO is still } \\
\text { far off }\end{array}$ & $\begin{array}{l}6-12 \\
\text { months } \\
\text { before IPO }\end{array}$ & $\begin{array}{l}\text { As a rule } \\
5-8 \text { Years. } \\
\text { after } \\
\text { start-up }\end{array}$ \\
\hline
\end{tabular}

\begin{tabular}{|l|l|l|l|l|l|}
\hline $\begin{array}{l}\text { Wainly to } \\
\text { Wevelop } \\
\text { business } \\
\text { concept } \\
\text { further }\end{array}$ & $\begin{array}{l}\text { E.g.: For } \\
\text { Product } \\
\text { Development }\end{array}$ & $\begin{array}{l}\text { Eg.: For } \\
\text { Initial } \\
\text { Marketing } \\
\text { Activities }\end{array}$ & $\begin{array}{l}\text { To Finance } \\
\text { Growth }\end{array}$ & $\begin{array}{l}\text { To cover } \\
\text { financial } \\
\text { needs until } \\
\text { sale of stock } \\
\text { to public }\end{array}$ & $\begin{array}{l}\text { Recovery of } \\
\text { invested } \\
\text { venture } \\
\text { capital for } \\
\text { reinvestment } \\
\text { in more } \\
\text { start-ups }\end{array}$ \\
\hline
\end{tabular}

Source: Compiled on the basis of information available from Business Plan Competition Hand Book (www.greatventure.co.nz), An Introduction to Raising Money From Venture Capitalists (www.onset.com), and 'Venture Capital and the Indian Financial Sector' by Ramesh, S \& Gupta, Arun. 
management by contributing their business experience and industry knowledge from their earlier participation with earlier entrepreneurial ideas in the young and start-up companies. This includes various guidance and advices in the areas of marketing, management recruitment, financial advice, contacts, and strategic direction. ${ }^{4}$

Firstly, the three circles at the top most part indicates three basic phases of a business venture; viz.; (1) early stage, (2) growth phase, and (3) transition to an established company. As the size of the circles changes, it indicates that the size of business operation as well as the market value of the business venture gets changed. During the early stage, when the business venture starts its operations from scratch, the level of the operations will be less with hardly any market value. As and when the business venture reaches the growth phase where the business starts expanding its operations from limited to a large scale manner, its level of operations increases. At this phase the market value of the firm still not improved to a higher level. But the final phase where the business venture acquires good reputation in the market place, the business venture transforms itself from a simple viable idea to a wellestablished company. This usually takes minimum five to eight years time. Level of the business operations will reach its zenith where the business starts earning high refurns. This leads to increase in the value of the firm to the maximum in the market.

Secondly, the stages in life cycle as well as the time scale associated with it represented along the horizontal axis and the risk perception represented along the vertical axis. The vertical arrow marks along the horizontal axis shows the degree of risk associated with the different stages of business venture from the inception till IPO. In the early phase, the degree of risk is more and as and when the business venture moves from early phase to growth phase and finally towards transforming itself in to a well-established company, the degree of risk slowly and steadily reduces.

Thirdly, as the life cycle or the time period usually taken for reaching different life cycle stages are divided into five and represented in the first, second and third rows below the horizontal axis. Almost all business ventures starts with an innovative, creative, novel, as well as a viable idea. Once these ideas survive the initial screening by the venture capitalists, the successful ones go for making prototype products. Only a few will succeed in this, on average, venture capitalists invest only about $1 \%$ of the opportunities presented by the entrepreneurs. ${ }^{5}$ Those prototypes pass out the first level reaches to the actual production of the product. At this level, the business venture has changed from laboratory or workshop to its own premises. Once it succeeds this level, the business venture has to look for the market and ultimately selling the products to meet the demands of customers. Once this third 
level is successfully completed, the time has come for the business venture for market growth. Here all possible combinations of demand potentialities are being analysed and accordingly appropriate strategies are formulated and implemented. This is generally done for capturing the market by way of making customers as well as the competitors fully aware about the company's products. The success of this fourth level leads to the fifth level, i.e.; market consolidation. Here the successful business venture after establishing their presence in the market tries to consolidate the market share by using appropriate business strategies. At this fifth level, the business venture wants to make sure that its market share and growth rate is more than any other competitor. Subsequently, the business venture reaches the sixth and the final level where it tries to dominate the market. Once the business venture reaches this level, venture capitalists can think about IPO of the business venture. Thus from idea to market domination, a business venture have to pass through various hurdles and the every time when the business venture overcomes hurdles makes it even more stronger to face the subsequent hurdles.

Finally, in the last three rows represents the six stages of venture capital financing, when such stages happens in the life of a business venture, and for what purpose venture capitalists provide assistance to the business ventures.

At the initial stage known as seed stage, the money provided by the venture capitalists are utilized by the entrepreneurs in developing the idea and making the business concept move further wherein a prototype of the product emerges. In the second stage characterized as start-up, the venture capitalists starts investing their first round of financing. Here, the business venture uses the capital mainly for product development and various supporting activities like buying of own premises, machineries, materials, etc. During the third stage, i.e.; market penetration, generally the second stage of financing is provided. This fund is used for the purpose of test marketing, product modification, as well as various other initial marketing activities. This funding is provided by venture capitalists only if the business venture shows some growth potential. The entrepreneur should try to establish the presence of the product or service in the market so as to capture a sizeable market share in future. The venture capitalist gives the third round of financing at the fourth stage for the purpose of market expansion. When the venture capitalists sees some more growth potentiality after the third stage financing, more money is provided for expanding the existing market base. Entrepreneurs should really make the venture grow at a faster rate. During the fifth stage, venture capitalists usually provides finance to bridge the gap to speedup the process of market consolidation. This type of financing usually called mezzanine or later stage or bridge financing. This market consolidation is usually undertaken by the venture capitalists, because they want to go for IPO within the next six months to one-year period. Most of the venture capitalists provide 
money to cover various financial needs of the business venture till the IPO takes place for selling the stock to public. The last stage in venture capital financing stage is exifing from the business venture. This happens normally after five to eight years after start-up. Technically this stage is called leveraged buyouts (LBO), liquidity event (LE), or initial public offering (IPO). Normally by this time, the business venture must have reached a stage where it dominates the market than other competitors in terms of market share and growth rate. The value of the firm automatically goes up leading to appreciation of its stock prices in the market. At this stage usually the venture capitalists go for IPO and tries to recover the money invested so far. This usually happens after five to eight years of waiting / gestation period. Thus a successful IPO helps a venture capitalist to compensate everything including the actual investment, the managerial \& non-managerial supportive assistance provided, as well as the long waiting time. The sale proceeds are usually kept or utilized for reinvestment purposes in more "ideas" of would be entrepreneurs as "seed" and "start-up" capital in future after appropriating sufficient profit.

\section{Origin, Development and Growth of Venture Capital}

Though the modern concept of venture capital started in USA with the formation of American Research \& Development Corporation in the year 1946 by Gen. Georges Doriot, a French-born military man who is generally considered as "the father of modern venture capital"; the concept of venture capital has been successfully transplanted (either in the original form or in variation) to almost all parts of the world over a period of 50 years. Presently venture capital industry became an integral part of the financial sector on par with or even overgrows the conventional financial institutions in many of the countries, because of its ability to promote entrepreneurial advancement and developing the economy in a manifold way. $A$ brief outline of the global venture capital industry with respect to different regions of the world and the respective share for the year 2001 is shown in Table - 1.

With respect to the amount of venture capital raised during 2001, North America and Europe controls $90 \%$ of the venture capital market. Asia Pacific region holds $8 \%$ share and the remaining $2 \%$ share is controlled jointly by Middle East \& Africa (1\%), Central \& South America (0.5\%), and Central \& Eastern Europe (0.5\%).

But with respect to the venture capital investment pattern, total share of North America (from $68 \%$ to $62 \%$ ) reduced by $6 \%$ and Western Europe (from $22 \%$ to $21 \%$ ) reduced by $1 \%$. This fall is reflected in the increase in other regions, mainly in Asia Pacific region (4\% increase). 
Another important aspect, which is clear from Table -1 is about the state of the economic development in the six regions. The first and the second regions consist of the most advanced countries in the world. In almost all the countries in these regions, industrial development started during the industrial revolution. Even some of the countries in the Asia Pacific region like Australia, New Zealand, Japan, China, and Hong Kong were also witnessed industrial revolution much before other countries in this region. This shows that before 1950's, the impact of industrial revolution was clearly visible in these countries.

TABLE - 1. GLOBAL VENTURE CAPITAL PLAYERS [2001]

\begin{tabular}{|c|c|c|c|c|}
\hline & Region & Countries & $\begin{array}{c}\% \text { share of } \\
\text { Amount } \\
\text { Raised }\end{array}$ & $\begin{array}{c}\% \text { share of } \\
\text { Amount } \\
\text { Invested }\end{array}$ \\
\hline 1. & $\begin{array}{c}\text { North America } \\
\text { (2) }\end{array}$ & USA, Canada & $68 \%$ & $62 \%$ \\
\hline 2. & $\begin{array}{c}\text { Western Europe } \\
\text { (17) }\end{array}$ & $\begin{array}{l}\text { UK, Germany, France, Italy, Sweden, } \\
\text { Netherlands, Spain, Belgium, Denmark, } \\
\text { Austria, Finland, Greece, Iceland, Ireland, } \\
\text { Norway, Portugal, Switzerland. }\end{array}$ & $22 \%$ & $21 \%$ \\
\hline 3. & $\begin{array}{l}\text { Asia Pacific } \\
\text { (18) }\end{array}$ & $\begin{array}{l}\text { Japan, Korea, Hong Kong, China, Australia, } \\
\text { India, Singapore, Taiwan, Indonesia, } \\
\text { Malaysia, Pakistan, Philippines, Sri Lanka, } \\
\text { Thailand, Vietnam, Myanmar, New Zealand }\end{array}$ & $8 \%$ & $12 \%$ \\
\hline 4. & $\begin{array}{l}\text { Middle East \& } \\
\text { Africa (4) }\end{array}$ & Israel, South Africa, Kenya, Nigeria & $1 \%$ & $2 \%$ \\
\hline 5. & $\begin{array}{l}\text { Central \& } \\
\text { South } \\
\text { America (4) }\end{array}$ & Argentina, Brazil, Chile, Mexico & $0.5 \%$ & $1 \%$ \\
\hline 6. & $\begin{array}{l}\text { Central \& } \\
\text { Eastern Europe } \\
\text { (11) }\end{array}$ & $\begin{array}{l}\text { Bulgaria, Czech Republic, Esonia, Hungary } \\
\text { Latvia, Lithuania, Poland, Romania, Russia, } \\
\text { Slovakia, Slovenia }\end{array}$ & $0.5 \%$ & $2 \%$ \\
\hline
\end{tabular}

Source : Compiled from informations from PWC Quarterly Reports (USA \& Canada), EVCA Venture Capital Directory (Both European Regions), Asian Venture Capital Journal; January 2003 (Asia Pacific), Ausiralian Veniure Capital Journal (Australia \& New Zealand), PWC \& 3i Report on 'Global Private Equity'. 
In almost all other countries the impact of industrial revolution started after 1950's. This is also one of the important factors of slow development of venture capital activities; which basically is meant for new industrial start-ups.

\section{World Scenario}

The venture capital industry began in the United States in 1946 and expanded there to Europe during 1980's and later to Asia to become a worldwide industry. ${ }^{6}$ The success of Silicon Valley has fuelled the growth of venture capital industry around the world. ${ }^{7}$

Venture capital financing is now being practiced by almost over more than 55 countries in six regions of the world. Some countries (mainly North America \& Western Europe) are having more experience in this field, they were able to organize well-developed infrastructure for the promotion of venture capital industry. This can be seen from the dissemination of information on the working of the venture capital industry in those countries. This also helped those countries to achieve the benefits of venture capital financing within a short period of time. At present almost all countries are having their own venture capital association to look after various aspects for the promotion and development of venture capital industry. The present status of venture capital industry with respect to the share of each region and the top 20 ranking and the investment over the last four years from 1998 to 2002 is given in Table - 2 and Table - 3.

Of the top 20 countries from Table No.2, none of them are from Central \& South America and Central \& Eastern Europe. Western Europe region leads with 9 lout of 17 countries) followed by Asia Pacific region with 8 (out of 18 countries). Only one country, Israel, ranks $13^{\text {th }}$ from Middle East \& Africa by over taking South Africa during 2000-2001. USA and Canada from North America region ranks as $1^{\text {st }}$ and $4^{\text {th }}$.

Even though Western Europe accounts for $45 \%$ of the top 20 countries, in terms of venture capital raised its share is only $22 \%$ and share of venture capital invested is only $21 \%$. It is far behind North America $168 \%$ and $62 \%$ share in venture capital raised and invested respectively). Third place is occupied by Asia Pacific region.

With respect to the ranking, only four countries kept their ranking unchanged from their earlier positions, viz., US (1), UK (2), Italy (7), and Netherlands (12). Nine countries improved their positions during 2000-01 (viz., China, Australia, Japan, India, Sweden, Germany, Canada, Belgium, and Denmark) and seven countries 


\section{TABLE - 2: GLOBAL VENTURE CAPITAL PLAYERS (Top 20 Countries from Regions of the World)}

\begin{tabular}{|c|c|c|c|c|c|c|c|c|}
\hline & North & Western & Asia & Middle & Centrol \& & Central \& & & RANK \\
\hline & & & & & & Europe & 2001 & 2000 \\
\hline & USA & & & & & & 1 & 1 \\
\hline & & UK & & & & & 2 & 2 \\
\hline & & Germany & & & & & 3 & 4 \\
\hline & Canada & & & & & & 4 & 5 \\
\hline & & France & & & & & 5 & 3 \\
\hline & & & Japan & & & & 6 & 10 \\
\hline & & Itoly & & & & & 7 & 7 \\
\hline & & Sweden & & & & & 8 & 11 \\
\hline & & & Korea & & & & 9 & 8. \\
\hline & & & Hong Kong & & & & 10 & 9 \\
\hline & & & China & & & & 11 & 17 \\
\hline & & Netherlands & & & & & 12 & 12 \\
\hline & & & & Israel & $\cdot$ & & 13 & 6 \\
\hline & & & Australia & & & & 14 & 19 \\
\hline & & & India & & & & 15 & 18 \\
\hline & & & Singapore & & & & 16 & 13 \\
\hline & & Spain & & & & & 17 & 15 \\
\hline & & & Taiwan & & & & 18 & 14 \\
\hline & & Belgium & & & & & 19 & above 20 \\
\hline & & Denmark & & & & & 20 & above 20 \\
\hline $\left.\begin{array}{l}\text { Rosed } \\
(200) \\
(s, 6)\end{array}\right)$ & $\begin{array}{l}102.80 \\
{[68 \%]}\end{array}$ & $\begin{array}{l}34.00 \\
{[22 \%]}\end{array}$ & $\begin{array}{l}12.10 \\
{[8 \%]}\end{array}$ & $\begin{array}{l}1.50 \\
{[1 \%]}\end{array}$ & $\begin{array}{c}0.60 \\
{[0.5 \%]}\end{array}$ & $\begin{array}{c}0.31 \\
{[0.5 \%]}\end{array}$ & & \\
\hline 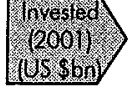 & $\begin{array}{l}62.80 \\
{[62 \%]}\end{array}$ & $\begin{array}{l}21.60 \\
{[21 \%]}\end{array}$ & $\begin{array}{l}11.90 \\
{[12 \%]}\end{array}$ & $\begin{array}{c}1.90 \\
{[2 \%]}\end{array}$ & $\begin{array}{l}1.30 \\
{[1 \%]}\end{array}$ & $\begin{array}{c}0.34 \\
\mid 2 \%]\end{array}$ & & \\
\hline
\end{tabular}

Source: Compiled from the report 'Global Private Equity 2002', A review of the global private equily and venture capital markets, PWC \& 3i, 2002

lost their positions during 2000-01 (viz., Korea, Hong Kong, France, Spain, Singapore, Taiwan, and Israel).

When we consider the ranking in different regions separately, North America and Western Europe, between 2000 and 2001 there is no major shift in the ranking between the countries. But in the Asia Pacific region, shifting of rank positions between countries are taking place in a dynamic way. Between Japan, Korea, Hong Kong, and China one can see a tough competition is taking place. Of the first 10 top ranking countries only three are from Asia Pacific region, but there are five top ranking countries from this region in the next ten toppers. 
Table No. 3 shows the details about the global venture capital status during 1998 to 2001. The amount raised is shown in bold figures, the percentage to the global total is shown in the parenthesis. The last column represents the compound average growth rate for the last five years from 1997-2001.

\section{TABLE - 3: GLOBAL VENTURE CAPITAL STATUS (RAISED \& INVESTED)}

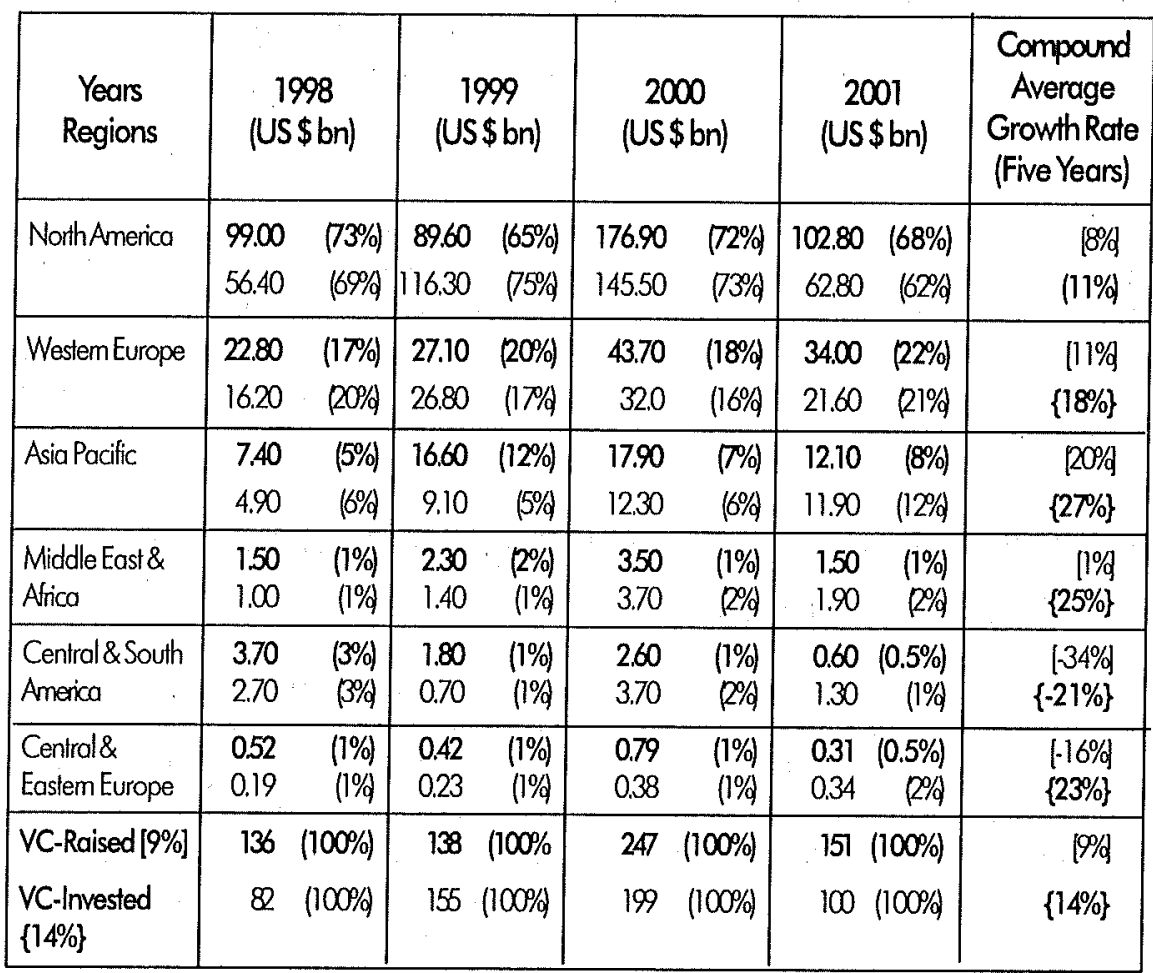

Source : Compiled from Global Privale Equity 2002, A Review of the Global Privale Equity and Venture Capital Markeis, Survey conducted by Price Woterhouse Coopers \& $3 \mathrm{i}$.

Figures shown in Bold represents Amount Raised

$\left({ }^{*}\right)$. Regions \% Share to the World Total

[*] Compound Average Growth Rate - Raised

$\left\{{ }^{*}\right\} \quad$ Compound Average Growth Rate - Invested 
During 1998 to 2001 both North America and Europe jointly controls almost $90 \%$ of the venture capital industry with respect to the amount raised and regarding the venture capital amount investment, on an average these regions controls $85 \%$ of the world market.

Most of the other four regions are just holding the positions without much major changes. The compounded average growth rate for the last five years for the venture capital industry as a whole is $9 \%$ for the amount raised and $14 \%$ for the amount invested. Only Western Europe (1 1\%) and Asia Pacific (20\%) regions achieved a higher growth rate. Though North America shows a positive growth rate, it is less by $1 \%$ than the global growth rate. Middle East \& Africa shows only $1 \%$ growth rate. Other two regions show a negative growth rate.

With respect to the growth rate in venture capital amount invested, Western Europe (18\%), Asia Pacific (27\%), Middle East \& Africa (25\%), and Central Europe (23\%) shows improvement over the global growth rate of $14 \%$. Central \& South America shows a negative growth rate (-21\%). In North America the growth rate was only $11 \%$. This decline in venture capital investment may be mainly due to the impact of September 11 to the US economy.

\section{Why Venture Capital Plays a Leading Role in Promoting Ideas}

As it is mentioned in the beginning of the paper that for the potential entrepreneurs having potential ideas in the concerned potential industrial sectors, the only way out is venture capital. This is true in the sense that these would be entrepreneurs can not sell their ideas to conventional financial institutions where the concept of collateral securities are the first criteria considered for granting financial assistance. The second criteria the other financiers look for with the entrepreneur are the ability to pay periodic repayment of the loan with interest. These two aspects are not usually seen with the would be entrepreneurs, thus comes the role and the importance of venture capitalists. As is clear from Figure No. 1 that the venture capitalists not only provides money to the newly emerging ideas of the entrepreneurs but also provides all types of non-financial assistance. Through this special process, the venture capitalist tries to add value to the business idea so that it becomes a successful enterprise within a period of 5 to 10 years. Once the enterprise becomes a successful one, the entrepreneur gets the fruits in the form of profits and the venture capitalist gets it in the form of capital gain.

Above all the three concepts, viz., venture capital, entrepreneurship, and economic development are interdependent. There are wide ranges of significant potential 
contributions that entrepreneurs and entrepreneurship can make to the development process. Entrepreneurship is a (1) powerful tool of job creation, (2) facilitates transfer of technology, (3) plays strategic role in commercialising new inventions and critical role in restructuring and transformation of economy, (4) makes markets more competitive and reduce both static and dynamic market inefficiencies, (5) stimulates redistribution of wealth, helps in improving social welfare of a country by harnessing dormant and previously overlooked talents, and finally (6) helps in creating new markets and facilitate expansion in to international markets.

Thus to make the impact of entrepreneurship, i.e., various activities usually done by the entrepreneur for the purpose of making the viable idea in to an enterprise, to be felt by an economy depends on how best the venture capitalists are financing the ideas of the entrepreneurs. This again depends on the phase of development, in which the economy is passing through, viz., agrarian or resource society, early industrialisation, mature industrialisation, and service and high-technology economy. As it is clear from Table No. 1 that most of the countries in the two regions, viz., North America and Western Europe reached the fourth phase. Thus depending on the level of development the country is in, the venture capitalists should try to support the ideas proposed by the entrepreneurs. So entrepreneurial activity begins in less developed countries with the formation of small business units with indigenous products and services, then moves on to modified products and services with the help of external help either in the form of imitation or collaboration, and then finally towards innovative and high technology entrepreneurship.

This being the case, it can be said that the venture capital is the only available source of fund which is available to the new generation of entrepreneurs who are having new and novel ideas, but insufficient capital to finance their idea. They do not have any other source of funds, because they do not have any previous track record to show to the conventional financiers, but only idea that, if properly financed and guided, can become successful enterprise in future. Here is the importance of venture capital, because the very meaning of venture capital connotes to the finance (mainly equity) to new and risky ideas of potential and able entrepreneurs. The significance of venture capital is to be given much importance, if a country wants to improve the entrepreneurial culture with a view to develop its economy. The role of venture capital in developing an economy is manifold, and all the roles played by entrepreneurship for economic development can be adequately assigned to venture capital also, because without this type of capital, it is difficult for entrepreneurship to play its role in economic development. Thus it can be concluded that venture capital has a greater role to play in the process of economic development. 
This process of promoting entrepreneurship leads to the development of the economy, because the new and novel ideas of the entrepreneurs are finding it easy to get adequate finance and thereby commercialisation of the product or service is taking place. This product evolution process of making the innovative ideas of the entrepreneur to a commercial success is actually helping to bridge the gap between the science / technology and the market place, which is of course, is the very basic process of economic development. Thus the gap between science and market place is being eliminated by three mechanisms, viz., existing government of the country, existing businesses with intrapreneurial climate, and establishment of new businesses by the potential entrepreneurs. ${ }^{8}$ These three mechanisms will work in a smooth and efficient manner only if adequate finance is available, and this finance is mainly contributed by venture capital. Thus it is clear that success of every business by potential entrepreneur with new and novel ideas, venture capital is the only source of finance and if the idea succeeds the product evolution process, economic development takes place.

\section{Economic Impact of Venture Capital}

It is not hard to understand why policy-makers are so fond of venture capital. Both academic and practitioner-oriented research now clearly demonstrates that venture capital investing adds value. ${ }^{9}$ Governments are increasingly aware that venture capital investing is critical to the health of their countries. Venture-backed companies historically produced a disproportionate share of new jobs, particularly well-paid and highly skilled jobs, and are a key source of research and development spending. ${ }^{10}$

The most important functions performed by the entrepreneur in the process of creating the enterprise (technically called the entrepreneurship) is job creation and playing a critical role in restructuring \& transforming the economy to a higher level. But to perform this task, entrepreneur requires the help of venture capitalists in the form of venture capital finance. Thus venture capital helps the entrepreneurs to generate the required amount of change, which leads to bridging the gap between science and market place.

Thus it indicates that venture capitalists has a greater role to play when it comes to the development of economy while giving financial assistance in the form of venture capital to the development and growth of new ventures promoted by entrepreneurs assistance in the form of venture capital to the development and growth of new ventures promoted by entrepreneurs, which has been proven by venture capital associations from countries like USA (National Venture Capital Association, i.e., NVCA), UK (British Venture Capital Association, i.e., BVCA), Europe (European Venture Capital Association, i.e., EVCA), Canada (Canadian Venture Capital 
Association, i.e., CVCA), and Australia (Australian Venture Capital Association Limited, AVCAL). Venture capital associations from other countries are in the process of conducting similar studies to find out the exact nature of the impact of venture capital.

Summary information of the study conducted by the above mentioned associations are shown in Table-4, which give a comparative analysis of economic indicators.

\section{TABLE - 4: ECONOMIC IMPACT OF VENTURE CAPITAL (Percentage Growth Rate of Economic Indicators During 1991 to 1996)}

\begin{tabular}{|l|c|c|c|c|c|}
\hline & $\begin{array}{c}\text { USA } \\
(1946)\end{array}$ & $\begin{array}{c}\text { UK } \\
(1947)\end{array}$ & $\begin{array}{c}\text { Canada } \\
(1962)\end{array}$ & $\begin{array}{c}\text { Australia } \\
(1984)\end{array}$ & $\begin{array}{c}\text { Europe } \\
(1980 \text { 's })\end{array}$ \\
\hline Employment & $20 \%$ & $15 \%$ & $26 \%$ & $20 \%$ & $15 \%$ \\
\hline Turnover & $35 \%$ & $34 \%$ & $14 \%$ & $42 \%$ & $35 \%$ \\
\hline Exports & $23 \%$ & $29 \%$ & $34 \%$ & $27 \%$ & $30 \%$ \\
\hline R\&D Investment & $33 \%$ & $28 \%$ & $40 \%$ & na & $25 \%$ \\
\hline
\end{tabular}

Source: Compiled from the informations ovailable in the Reports published in the year 1996 by NVCA, BVCA, CVCA, AVCAL, and EVCA on 'Economic Impact of Venture Copital'.

The economic indicators shows that venture capital financing helps entrepreneurs in generating more employment, increased turnover, increased export income, and also improvement over R\&D investment which in turn leads to more and more innovations resulting into more and more products and services to meet customer needs by bridging the gap between science and market place.

With respect to turnover, the average annual growth rate for the years 19911996, Australia is the highest with 42\%. In the case of Employment generation (26\%), Revenue from Exports (34\%), and R\&D investment (40\%), Canada leads among other players.

The recent study conducted in the US by NVCA in association with DRI-WEFA, one of the world's leading economic and information consulting firms, shows that venture capital-funded companies contributed nearly $\$ 1.1$ trillion to GDP and directly accounted for 12.5 million jobs in 2000 . If supporting businesses that deliver goods and services to these venture-backed companies were also includes in the total, the jobs number increases by a multiplier of 2.2 , translating to 27 million jobs, a staggering percentage of total US employment. " 
In addition to generating jobs and revenues, companies that were originally venturebacked out performed other public companies on a relative basis across the number of economic measures. For every $\$ 1,000$ in assets between 1980 and 2000 venturebacked companies generated more sales, paid more taxes ( $\$ 58.8$ billion), produced more exports ( $\$ 21.7$ billion), and invested more in research and development (\$157.3 billion).

The break-up of jobs created and the revenues generated by venture-backed companies are shown in Table -5 .

\section{TABLE * 5: JOBS CREATED \& REVENUES GENERATED BY VENTURE BACKED COMPANIES}

(By Industry for 2000)

\begin{tabular}{|lr|r|r|}
\hline \multicolumn{2}{|c|}{ Industry } & Jobs Created & $\begin{array}{r}\text { Revenues } \\
\text { Generated } \\
\text { (\$ billions) }\end{array}$ \\
\hline Consumer & {$[26 \%]-\{18 \%\}$} & $1,126,462$ & 131.89 \\
Computer Related & {$[20 \%]-\{28 \%\}$} & 850,187 & 204.24 \\
Medical/Health & {$[15 \%]-\{11 \%\}$} & 646,429 & 80.29 \\
Communications & {$[07 \%]-\{08 \%\}$} & 293,722 & 60.94 \\
Industrial/Energy & {$[06 \%]-\{07 \%\}$} & 265,238 & 55.00 \\
Electronics & {$[05 \%]-\{07 \%\}$} & 237,308 & 54.42 \\
Biotechnology & {$[01 \%]-\{02 \%\}$} & 61,090 & 14.55 \\
Other & {$[20 \%]-\{19 \%\}$} & 802,696 & 134.60 \\
\hline TOTAL & & $4,282,132$ & 735.93 \\
\hline
\end{tabular}

Source: Compiled from the National Venture Capital Association Data.

$\left[^{*}\right]$ - Indicates $\%$ of job created to the total

$\left\{{ }^{*}\right\}$-Indicates $\%$ of revenue generated to the total.

Though more than half of these jobs were in the manufacturing and retail sector, computer related and service sector generated more than half of the revenue generated. In terms of jobs created, the first and second places are occupied by consumer goods industry (26\%) and computer related industry (20\%). But with respect to the revenue generation, these two sectors shows a complete overturn, first position is occupied by computer related industry (28\%) and the second position is occupied by consumer goods industry (18\%). All other categories of industries occupies the remaining positions with respect to the employment generation as well as the revenue generation in the same pattern. 
A similar study conducted in UK by the BVCA in association with Bannock Consulfing, a leading firm at the forefront of research into European venture capital and private equity also indicates that during five year period to 2001-2002, venturebacked companies increased staff level by an average $23 \%$ per annum compared to national growth rate of $1.5 \%$ per annum. Total number of people employed in these venture-backed firms is 2.9 million, which is equivalent to $16 \%$ of the current private sector workforce. The annual sales growth rate during the same period was $30 \%$ per annum, Investment growth rate was $25 \%$ and exports increased by $20 \%$.

All these statistical informations available from various research reports clearly indicate that venture capital helps in promoting the economy, hence it has the potentiality of helping the entrepreneurs in successfully transforming their ideas in to a profitable enterprise.

\section{Future Trend}

Though it appears that the concept of venture capital is presently being practiced in almost all parts of the world, the future looks very uncertain. The slow down of the development in the economies of most of the countries resulted in reduced investment activities around the world. Table -6 explains some of the future trends of global venture capital industry.

With respect to the amount of venture capital raised $(A)$ and also the amount of venture capital invested (B), except during 2000-2001, shows an upward trend. Though this upward trend is not increasing over the years, it clearly shows that the money is being invested in venture-backed companies. But during 2000-2001, almost $50 \%$ reduction in the venture capital investment activity around the world happened. This may be due to the uncertainty prevailing in most of the countries due to the slow down of the US economy.

Another important factor, which is clear from Table -6 , is that of the percentage of utilisation $(B / A)$ of venture capital fund. Only during 1999 the percentage of utilisation around the world was $112 \%$, i.e., the amount of venture capital investment ( $\$ 199$ billion) was more than the amount of venture capital raised ( $\$ 138$ billon) in that year. 


\section{TABLE - 6: GLOBAL VENTURE CAPITAL ACTIVITY [US \$ Billion]}

\begin{tabular}{|l|l|c|c|c|c|c|}
\hline & 1997 & 1998 & 1999 & 2000 & 2001 & $2002^{*}$ \\
\hline Venture Capital Funds Raised [A] & 108 & $\begin{array}{c}136 \\
(26) \Uparrow\end{array}$ & $\begin{array}{c}138 \\
(2) \Uparrow\end{array}$ & $\begin{array}{c}247 \\
(79) \Uparrow\end{array}$ & $\begin{array}{c}151 \\
(39) \Downarrow\end{array}$ & $100^{*}$ \\
\hline Venture Capital Investment [B] & 59 & $\begin{array}{c}82 \\
(39) \Uparrow\end{array}$ & $\begin{array}{c}155 \\
(89) \Uparrow\end{array}$ & $\begin{array}{c}199 \\
(28) \Uparrow\end{array}$ & $\begin{array}{c}100 \\
(50) \Downarrow\end{array}$ & $50^{*}$ \\
\hline Percentage of Utilisation (\%) [B/A] & $55 \%$ & $60 \%$ & $112 \%$ & $81 \%$ & $66 \%$ & - -na- \\
\hline Balance Fund Available for Investment & $(+) 49$ & $(+) 54$ & $(-) 17$ & $(+) 48$ & $(+) 51$ & -na- \\
\hline
\end{tabular}

\section{Source :}

Compiled from Global Private Equity 2002, A Review of the Global Private Equity and Venture Capital Markeis, Survey conducted by Price Waterhouse Coopers \& 3i.

Represents Estimated Figures.

na Not applicable

(t) Investment less than the fund raised; balance amount available.

(-) Invesiment more than the fund raised; balance amount not available.

$\Uparrow$ Percentage increase from last year.

ઔ Percentage decrease from last year.

Remaining years, amount of venture capital raised was more than the amount of venture capital invested. This reflects on the fund utilisation capability of the venture capital firms (technically called venture capitalists). Except for 1999, funds were not fully utilized. Many reasons can be attributed, but what is important is that over the years a staggering amount of $\$ 185$ billion became surplus. Again the coming year more venture capital funds will be raised and naturally more amounts becomes excess. Hence the need of the hour is finding potential avenues where $\$ 185$ billion surplus amount can be invested profitably, other wise the contributors (viz., investors) may demand for the repayment of their funds. Thus the venture capitalists first needs to identify viable ventures first for this excess amount, else the consequences will have a major impact on the global economy. Taking in to consideration the above aspect as well as many other factors, almost $30 \%$ reduction in venture capital amount to be raised and in terms of venture capital investment almost $50 \%$ reduction is anticipated. Though the future looks little more than uncertain, venture capital financing is the only financial instrument contributed more towards economic development than any other investment alternative. 


\section{End Notes}

1. Subhash. K.B, Significance of Venture Capital and Entrepreneurial Development in South India, Doctoral Thesis submitted at the University of Calicut, Kerala, 1998, pp 21-22

In the US, venture capital includes only the early stage financing. If later stage financing is included, it is called Private Equity. In Europe, venture capital is a subset of private equity and refers to equity investments made for the launch, early development, or expansion of a business. So these two terms are used interchangeably in Europe.

2. Helsing, Roy. G, Venture Capital Inside Out - An Entrepreneur's Guide to How the System Works, Transwest Ventures Inc, California, 1988, pp 6-6.

3. Aylward, Anthony, Trends in Venture Capital Finance in Developing Countries, IFC Discussion Paper \# 36, World Bank, Washington DC, pp 1-2.

4. Report on The Economic Impact of Private Equity in the UK, British Venture Capital Association, 2002, pp 13-14.

5. Nuechterlein, Jeffrey. D, The Role of Stant-up Financing in the United States, Europe, and Asia, Global Venture Capital Association, http://www.tvea.org.tw/outlook.doc last checked 09/ 02/2003.

6. Bruton, Gary. D, Venture Capitalists in Asia : A comparison with the USA and Europe, Vlerick Working Paper 2002/15, Vlerick Leuven grent Management School.

7. Koh, Francis. C.C \& Koh, Winston. T.H, Venture Capital and Economic Growth; An Industry Overview and Singapore's Experience, Working Paper, Singapore Management University, Singapore.

8. Hisrich, Robert. D \& Peters, Micheal. P, Entrepreneurship, Tata McGraw-Hill, New Delhi, pp $10-17$

9. Megginson, William. L, Towards a Global Model of Venture Capital, Research Paper presented at the Shanghai Seminar on Venture Capital Development, Fudan University, Shanghai, PRC in December 1999.

10. Nuechterlien, Jeffrey, op cit.

11. The Economic Impact of Venture Capital Industry on the US Economy, Venture Impact, NVCA \& DRI-WEFA, 2002 